\title{
Conceptual Insight into Generic Corporate Identity in the Banking Industry and a Semiotic Evidence of Its Presence in Professional Services Firms (PSFS)
}

\author{
Olutayo Otubanjo ${ }^{1}$ \\ ${ }^{1}$ Lagos Business School, Pan-African University, Lagos, Nigeria \\ Correspondence: Olutayo Otubanjo, Lagos Business School, Pan-African University, Km 22 Lekki Epe \\ Expressway Ajah, Lagos, Nigeria. Tel: 234-808-608-6816. E-mail: totubanjo@lbs.edu.ng
}

Received: August 13, 2012 Accepted: August 23, 2012 Online Published: November 2, 2012

doi:10.5539/ijms.v4n6p66 URL: http://dx.doi.org/10.5539/ijms.v4n6p66

\begin{abstract}
Purpose of this paper: This paper aims to provide an insight into the dominant arguments in generic corporate identity literature - and offers evidence of the presence of generic corporate identity in professional services industry.

Design/method/approach: Existing literature on generic corporate identity is reviewed leading towards the development of three conceptual perspectives of generic corporate identity, namely active, passive and parenthetic. The weakness of existing theoretical literatures (in relation to their inability to explicate how generic corporate identity develops) is highlighted. Consequently, a new process model grounded on the notion of institutional isomorphism is presented to fill this gap. A semiotic deconstruction of corporate identity statements in annual report and accounts of the big four professional services firms in the United States is presented to provide evidence of the presence and emergence of generic corporate identity in professional services firms.
\end{abstract}

Findings: A number of findings emerged in this study. First are three pedagogical themes of generic corporate identity. Second is a four stage generic identity development process model, which explicates how generic corporate identity emerges. Third, a semiotic deconstruction of some sections of annual report and accounts of the big four professional services firms in the United States supports the presence and emergence of generic corporate identity in professional services firms.

Theoretical implication: The introduction of a generic corporate identity process model in this study clarifies how generic corporate identity evolves. This clarification aids the understanding of the development process of generic corporate identity, which until date remains vague, fuzzy and unclear. In addition, the semiotic deconstruction of texts, which gives insight into the presence of generic corporate identity in Professional Services Firms (PSF), takes the argument in marketing literature a step further. Specifically, the outcome of the deconstruction of texts indicates that the problem of generic corporate identity is not a banking problem alone but a professional services issue as well. The study adds to existing knowledge on the theory of generic corporate identity and contributes towards an understanding of corporate identity theory in general.

Practical implications: Insights into the elements that influence the development of a generic corporate identity imply that managers can map out plans that enable firms or clients to challenge or avoid the acquisition of generic corporate identities. By circumventing the development of generic corporate identity, firms develop distinct corporate identities, which position them competitively in the business environment.

Limitation of study and future research direction: The empirical evidence presented in this study merely supports the presence of generic corporate identity in professional services firms. The study does not address this issue in other service industries such as tourism, hospitality, information technology. The inability to pursue this study in these industries presents an opportunity for future research.

Originality and value of paper: The review of literature indicates that existing studies on corporate identity has focused mainly of the factors that trigger the development of a generic corporate identity without a detailed explanation how this concept emerged. This paper makes a departure from extant theory and adds an original contribution to existing literature by providing a theoretical analysis, which gives an insight into the stage by stage processes that trigger the development of a generic corporate identity. 
Keywords: corporate identity, generic corporate identity, institutional isomorphism, mimetic isomorphism, coercive isomorphism, normative isomorphism

\section{Introduction}

The concept of generic corporate identity is generally accepted as a phenomenon reflective of a strong homogeneity (Otubanjo, 2008; He and Balmer, 2005) dominating an industry, sector or industry group (Morison, 1997; Howcroft and Lavis 1986). It is indicative of a collective business culture and similar business behaviour (Olins, 1978; Balmer and Wilkinson, 1991; Wilkinson and Balmer, 1996) expressed unconsciously by firms within a specific industry. Thus, it is a common rather than specific characteristic dominating the business activities of firms within an industry (He and Balmer, 2005).

The development of a generic corporate identity has been endorsed and recognised as one of the important subjects at the heart of corporate identity literature (He and Balmer, 2005; Balmer and Wilkinson, 1991; Howcroft and Lavis, 1986; Olins, 1978; Balmer and Greyser, 2003). In fact, the notion of generic corporate identity is considered to be one of the most challenging problems facing academics and practitioners (Balmer and Wilkinson, 1991). Thus, it has continued to engage and draw the attention of authors.

While several attempts have been made to explicate the concept (see the works of He and Balmer, 2005; Balmer and Wilkinson 1991; Balmer and Wilkinson, 1996) and the factors that trigger it in the banking industry, the processes through which this concept evolves have been unduly ignored and disregarded. In addition, it appears that marketing literature (He and Balmer, 2005; Morison, 1997; Howcroft and Lavis 1986; Balmer and Wilkinson, 1991; Wilkinson and Balmer, 1996) have for some time associated the notion of generic corporate identity to banks alone. However it appears that this may not truly the case. Evidence is emerging that it is equally a professional service issue.

The author makes an attempt to address these gaps by drawing upon DiMaggio and Powell's (1983) influential institutional theory of mimetic, coercive and normative isomorphism to develop a process model. This model demonstrates how generic corporate identity evolves. In addition, the study provides evidence to demonstrate the presence of generic corporate identity in Professional Services Firms (FSF).

The development of a generic corporate identity process model is valuable and important for a number of reasons. First, it provides a detailed and comprehensive insight into the procedural and/or stage by stage processes, factors and structures, which trigger the development of a generic corporate identity. Second, an understanding of the fuzzy and unclear procedural (stage by stage) factors and characteristics that activate the development of this concept imply that managers responsible for corporate identity can map out plans that enable firms or clients to challenge or combat these factors each step of the way. By circumventing the development of generic corporate identity (each step of the way), firms can attempt to develop distinct corporate identities, which position them competitively in the business environment. Third, the development of this model is important because it furthers the understanding of the theory of corporate identity and adds to the development of the concept of corporate identity literature in general.

In order to fully address the objective set in this study, this paper has been divided in five dominant sections and this section constitutes the first. The paper continues in section two with a review of existing works on the concept of generic corporate identity. This is followed by a semiotic analysis of corporate identity statements appearing in the annual report of account of the big four professional services firms in section three. This section ends with a review of the weaknesses found in the generic corporate identity literature. In the fourth section, a four stage process model grounded on DiMaggio and Powell's (1983) mimetic, coercive and normative isomorphic institutional theory is advanced. A discussion highlighting the findings from this study is presented and the study is concluded in section five.

\section{Nature of Generic Corporate Identity in Literature: Three Theoretical Perspectives}

The review of literature indicates that the concept of generic corporate identity have been constructed actively, passively and parenthetically. Actively constructed discourse focus on key arguments in works that are devoted primarily to the concept of generic corporate identity. Works drawn together under actively constructed discourse approach the notion of generic corporate identity thoroughly, painstakingly and comprehensively. Passively constructed discourse address studies that are not devoted primarily to the concept of generic corporate identity but nevertheless provide a useful, significant and considerable insight into the understanding of the concept of generic corporate identity. Under parenthetically constructed discourse, theoretical literatures that briefly highlight the nature of generic corporate identity in-passing or incidentally are drawn together. 
Actively constructed discourse: The notion of generic corporate identity has attracted the attention of a handful of authors who in their works (Wilkinson and Balmer, 1996; Morison, 1997; Harris, 2002; He and Balmer, 2005) constructed this concept thoroughly, comprehensively and painstakingly. Chronologically, Wilkinson and Balmer's (1996) paper provides one of the pioneering works devoted primarily to generic corporate identity. They argued that the development of generic corporate identity in the British banking industry have been brought about by the British virtues of security, reliability and innate conservativism reinforced by qualitative and quantitative monetary policies by the Bank of England. Although, there are further claims in Wilkinson and Balmer's (1996) work that generic corporate identity has also developed in the British banking industry owing to limited degree of price and product competition and similar growth rates, it is however not clear from Wilkinson and Balmer's (1996) study whether these commonalities in Britain were provoked by a variety of British monetary and financial policy guidelines. Importantly however, Wilkinson and Balmer's (1996) argument is empirically grounded on a study of the British Building Society, which supports the claim of the pre-eminence of generic corporate identity in the British banking industry.

The dominance of generic corporate identity in the British banking industry is also highlighted in Morison's (1997) thesis. Drawing from a case of Midland Bank (Now HSBC), Morison (1997) argued that the generic nature of corporate identity in the British banking industry manifests through the adoption of a monolithic identity system, which allows major operators of this industry to pursue a variety of business activities in the name of their parent banks. Morison's (1997) thesis traces the failure of the banks to develop a pluralist corporate identity to three important issues. First is a similarity in the banks' corporate history with reference to how these banks developed, grew and expanded over time. Second is the nature of banking business, which forces British banks and financial institutions to jettison separate identities of other businesses acquired; and third is the regulatory business environment in which banks pursue their businesses.

Eight years after Morison (1997) drew attention to the efforts by banks to break the generic corporate identity that dominated the British banking industry, He and Balmer (2005) also confirmed the subsistence of this mould. They argued that the survival of this phenomenon in recent times is due largely to the continued survival of the same antecedents (i.e. historical legacy; industry regulation etc) that brought this phenomenon to life in the first place. This argument has also been confirmed by Harris (2002), who confirmed the ascendancy of similar causative industry characteristics.

Passively constructed discourse: Several studies, which though were not primarily devoted to the notion of generic corporate identity, also highlighted some of the factors that triggered the development of a monolithic or generic corporate identity structures. For instance Olins's (1978) work, which focused mainly on corporate personality (in part) highlighted the dominance of the generic corporate identity structure in the British financial industry. Olins (1978) argued that operatives of the British Building Society were similar in their corporate or business behaviour and it was in fact difficult (if not impossible) to tell or differentiate one British Building Society operative from the bother.

Balmer and Stotvig's (1997) paper, which is also devoted in part to the notion of generic corporate identity furthered Olins (1978) argument on the pre-eminence of generic corporate identity by drawing attention to the existence of two categories of generic private bank identities (i.e. 1-arrivisties; 2-traditionalists) in the British banking industry. As Balmer and Stotvig (1997) observed, the British banking industry is dominated by the prevalence of private financial institutions acquired by high street retail banks, and who to some degree have maintained a part of what constitutes the identities of their original institution. The traditionalists represent a handful of private banks established between the 1600s and the early 1900s. The arrivisties however are those financial institutions established in recent times. Drawing from a case study of privately owned banks, Balmer and Stotvig (1997) makes the point that generic private bank identities (i.e. arrivisties or traditionalists) emerged from a myriad of common characteristics in relation to their business and corporate history, ownership, promotional strategy and service quality.

Parenthetically constructed discourse: this aspect of generic corporate identity discourse draws together theories (highlighted or mentioned in passing) in the course of the pursuit of other issues. Importantly, the works of Professor John Balmer and Prof. T.C. Melewar (Baker and Balmer, 1997; Melewar and Jenkins, 2002) both of Brunel Business School, Brunel University London, have again featured prominently in this regard. For instance, while addressing issues about the initiation and development of a corporate visual identity programme for a leading British university, Baker and Balmer (1997) highlighted the peculiarity of the problem of generic corporate identity, not just to British banking industry but to firms operating in oil and air transport industries and the British education industry (Melewar and Akel, 2005). This position has been tacitly supported by Melewar and Jenkins (2002); Melewar and Wooldridge (2001) and Melewar (2003). Similarly, a study on the 
meaning, management and measurement of the concept of corporate identity led van Riel and Balmer (1997) to call for further studies that would better explicate the notion of generic corporate identity.

\section{Evidence of a Generic Corporate Identity in Professional Services Firms (PSF)}

The review of theoretical literature (towards the end of the last paragraph) signifies the prevalence of the concept of generic corporate identity in other industries other than banking. In fact, attention has been drawn by some management authors (see Løwendahl, 2005; Empson, 2001) to the pre-eminence of this concept in other important business sectors such as the Professional Services Firms (PSF). Under this paragraph, the author strengthens this anecdotal position by deconstructing texts containing the corporate identities of the four biggest PSFs in the world (Ernst \& Young; PricewaterhouseCoopers; Deloitte and KPMG (Forbes, 2007) as a way of providing empirical evidence of the pre-eminence of generic corporate within this sector.

\subsection{The Deconstruction of Corporate Texts}

Texts culled from the annual report of accounts of the four biggest PSFs (i.e. 1-Ernst \& Young; 2-PricewaterhouseCoopers; 3-Deloitte Touche Tohmatsu and 4-KPMG) dominating the world's professional services industry (see Forbes, 2007) are drawn and deconstructed semiotically following Barthes (1967; 1973, 1988) influential (Phillips and Brown, 1993) study on semiotic method. Professional services industry is drawn because it is one of the least studied areas in business, yet it contributes significantly to the global economy (Løwendahl, 2005). The four biggest professional services firms in the US are employed because they dominate business activities in this sector (Forbes, 2007) and also because they are the most experienced and most diversified professional services firms in the US. The use of corporate identity texts, which appear in annual general report of the firms under investigation, is hinged on their ability to provide a comprehensive insight into the homogeneous characteristics that trigger the development of a generic corporate identity. Similarly, corporate identity texts published in the 2007 business year of the four biggest professional firms was deconstructed because they provide an updated/latest version of a variety of characteristics that constitute the corporate identity of these firms.

The use of semiotic method is founded on its capacity to deconstruct and provide deeper insight into corporate level messages being expressed in a text. It is also adopted in this study with the hindsight of its ability to interpret signs most especially words (Eco, 1976; Chandler, 2007). In addition, semiotics was deemed appropriate because it is generally useful in dissecting and examining cultural codes sensitively to unearth interpretational subtleties (Merris, 2001; Leiss et al., 1986) as well as messages constructed in texts.

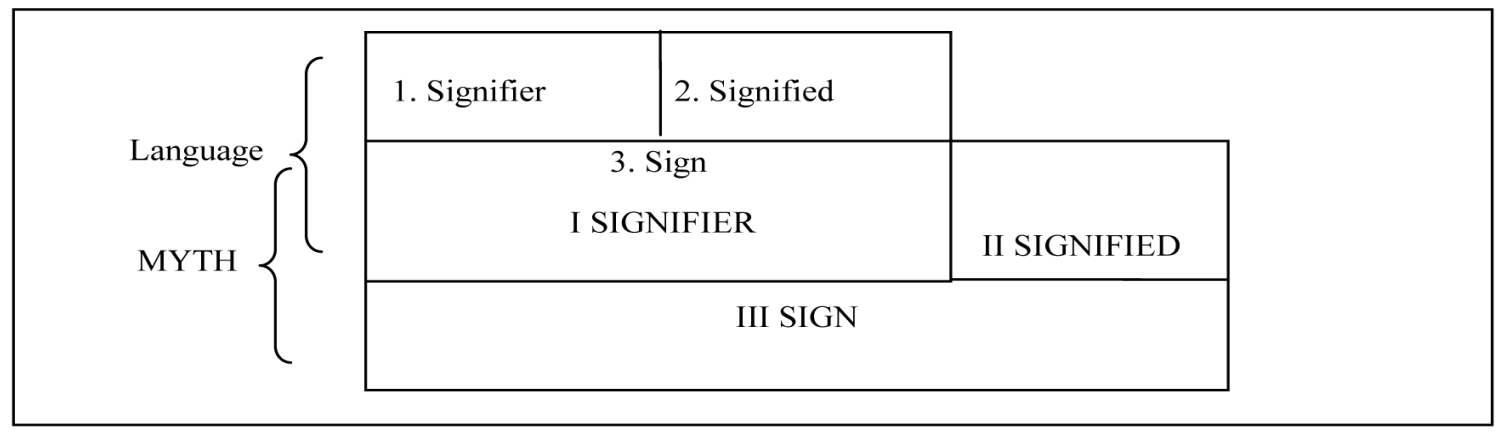

Figure 1. Connotation

Source: Barthes, 1972b, p. 114

The semiotic method of analysis evolves from de Saussure's (1916) work, which advocates the use of language as a system of sign (Hall, 1999; Mick, 1986) but controlled by a larger body of knowledge called semiology (Mick, 1986) or semiotic analysis. The semiotic method based on de Saussure's philosophy can be condensed into three stage processes namely denotation, connotation and myth (Barthes, 1967; 1973, 1988). The denotation stage gives a formal description of the advertisement and its paradigm. Connotation brings together the signifier and signified (de Saussure, 1916) and converts it to a signifier and attaches this to an additional signified (see Figure 1). The myth stage present an ideology based on the integration of the denotations and connotations 
stages of the deconstructive process. In the following paragraphs the author deconstructs four texts culled from the annual report of the four biggest PSFs via semiotic method.

\subsubsection{Denotation Stage}

Ernst \& Young: This electronic text, containing four paragraphs is printed in black ink on a white background with EYGothicCondMedPS character and 14 point font size. This text, which has been constructed without a headline, is syndicated in the first page of Ernst \& Young's 2007 annual report of account. This text, which presents a discourse of issues relating to Ernst \& Young's identity (i.e. who it is, what it is, what it does, the nature of its business, how it carries out its business), is presented in Table 1 below:

Table 1. Corporate identity profile

\begin{tabular}{l} 
Corporate identity profile, Ernst \& Young \\
\hline Every person in the world has potential. As \\
does every company and every community. \\
A person's ability to achieve their potential is \\
impacted by their surroundings and by access \\
to quality education. For companies, market \\
conditions, internal controls and governance \\
play a key part. For communities, it is in the way \\
they balance the opportunities and challenges \\
they face. \\
At Ernst \& Young, we are in the business of \\
delivering seamless, consistent, high-quality \\
professional services worldwide. We have \\
130,000 women and men who possess a \\
wide array of talents, and who deliver these \\
services every day. \\
What brings our 130, ooounique individuals \\
together is a belief that every person, company \\
and community needs help to achieve their \\
potential; and we strive to use our talents to \\
make a difference - a real difference - for \\
those people, clients and communities.
\end{tabular}

Source: Ernst \& Young (2007, p. 1)

$K P M G$ : This is a short (two column) electronic text (of five paragraphs) printed in white ink on a blue background with Univers LT Std 55 character and 10 point font size. This text, entitled "Who We Are", is syndicated in page four of KPMG's 2007 annual review and statement of accounts. The full text of this document, which highlights the key elements of KPMG's corporate identity, is presented in the paragraph below:

Table 2. Corporate identity profile

\begin{tabular}{lll}
\hline Who We Are & $\begin{array}{l}\text { Corporate identity profile, } \\
\text { The } 123,000 \text { people within KPMG } \\
\text { member firms worldwide provide a } \\
\text { range of professional services that } \\
\text { help clients to meet challenges and } \\
\text { respond to opportunities. }\end{array}$ & $\begin{array}{l}\text { Our focus on global industries helps } \\
\text { KPMG people to develop a rich } \\
\text { understanding of clients' businesses } \\
\text { and the insight, skills, and resources } \\
\text { required to address industry-specific } \\
\text { issues and opportunities. }\end{array}$ \\
$\begin{array}{ll}\text { We provide Audit, Tax, and Advisory } \\
\text { services, delivering a globally consis } \\
\text { tent set of multidisciplinary financial } \\
\text { and accounting skills and capabilities } \\
\text { based on deep industry knowledge. }\end{array}$ & $\begin{array}{l}\text { Our history spans three centuries } \\
\text { and features a number of high-profile } \\
\text { mergers, leading to the merger of } \\
\text { Peat Marwick International and } \\
\text { Global capability and consistency are } \\
\text { central to the way we work. By provid } \\
\text { inglividual member firms, in } 1987 .\end{array}$ \\
$\begin{array}{l}\text { Today, KPMG is a truly global } \\
\text { quality of service and behavior around } \\
\text { the world, we can work with them } \\
\text { wherever they choose to operate. }\end{array}$ & $\begin{array}{l}\text { organization, with operations in } \\
\text { more than } 145 \text { territories. }\end{array}$ \\
\hline
\end{tabular}

Source: KPMG (2007, p.4) 
Deloitte Touche Tohmatsu: This four paragraph electronic text entitled "Living the brand" is printed with a white background. It appears on page 41 of Deloitte Touche Tohmatsu's annual review and report of accounts and discusses the key elements of Deloitte Touche Tohmatsu's corporate identity. The full text in this document is divided into two segments (i.e. 1-intro and 2-main body copy). The text begins with an intro. The intro is printed in a light blue Frutiger-45Light character with 15 point font size. The intro highlights some of the key roles of corporate brand within Deloitte Touche Tohmatsu's business operations. The main body copy (printed in a light blue Frutiger-45Light character with 10 point font size) furthers the discourse under the intro by making reference to its human capital, distinctive features and how a combination of these unique corporate characteristics distinguishes Deloitte Touche Tohmatsu from other management consulting firms with similar business inclinations.

Table 3. Corporate identity profile

$\frac{\text { Corporat identity profile, Deloitte Touche Tohmatsu }}{\text { Living the brand }}$

\author{
A vibrant and compelling brand is essential to the strength and \\ success of the Deloitte organization and helps to move the \\ organization closer to becoming the standard of excellence. But it is \\ brand in a special sense. "Brand, for Deloitte, is not a commercial \\ instrument," says Ludo De Keulenaer, DTT Managing Partner, \\ Brand. "It's not about our 'product,' or even what Deloitte does. It's \\ about who we are and what we stand for."
}
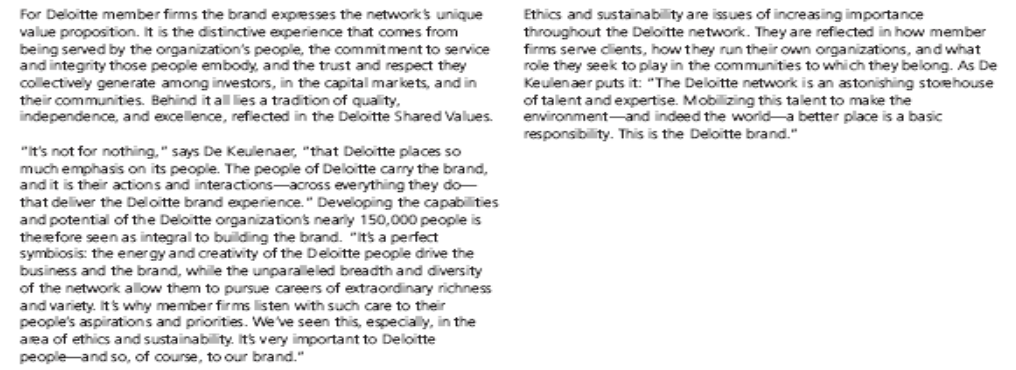

Source: Deloitte Touche Tohmatsu (2007, p. 41)

PricewaterhouseCoopers: This is an electronic text printed in white ink on a light blue background with HelveticaNeue-Roman character and 18 point font size. This text, which has been constructed without a headline, is syndicated in page two of PricewaterhouseCoopers's annual report of account of 2007. This text, provides a brief analysis of PricewaterhouseCoopers's identity with emphasis on what it does; staff strength; the nature of its business and its location. This text is presented in Table 4:

Table 4. Corporate identity profile

\begin{tabular}{c}
\hline Corporate identity profile, PricewaterhouseCoopers \\
\hline $\begin{array}{l}\text { PricewaterhouseCoopers provides } \\
\text { industry-focused assurance, tax and } \\
\text { advisory services to build public trust } \\
\text { and enhance value for its clients and } \\
\text { their stakeholders. More than } 146,000 \\
\text { people in } 150 \text { countries across our } \\
\text { network share their thinking, experience } \\
\text { and solutions to develop fresh } \\
\text { perspectives and practical advice. }\end{array}$ \\
\hline
\end{tabular}

Source: PricewaterhouseCoopers (2007, p. 2) 


\subsubsection{Connotation Stage}

Ernst \& Young: The combination of these names is reflective of a pure synergistic (nonconcatenated) redeployment, which often emerges when an acquiring firm keeps the identity and brand name of the acquired firm as the name of a subsidiary or division in the company (Jaju et al, 2006). The combination of these names also indicates that it is a strong multinational professional firm. The first two paragraphs in Ernst \& Young's text does not bear a direct relationship with its identity, therefore, the connotative analysis of Ernst \& Young's text begins with the deconstruction of the issues highlighted in the third paragraph. Importantly, the third paragraph implies that Ernst \&Young is a multinational consulting and advisory services firm that provides a standardized top quality services through a large staff strength of 130,000 knowledgeable and well-informed employees (with a variety of unique problem solving skills) at their various offices located all over the world. The fourth paragraph justifies the assembly of such large staff strength (at their various locations throughout the world) by arguing that Ernst \& Young use its resources to support client's businesses and the communities in which these businesses operate. Inevitably employees equally benefit from these services.

KPMG: KPMG is an abbreviation formed by combining the names of Peat Marwick International (PMI) and Klynveld Main Goerdeler (KMG) - the benefactors of KPMG (see Capowski, 1993). The combination of these two firms indicates that KPMG is a strong multinational firm. This text contains five paragraphs. The first and second paragraphs defines KPMG as a multinational firm with large staff strength of 123,000 offering a variety of standardized management consulting services such as auditing, tax, business advisory and multidisciplinary financial accounting services. As KPMG argues, these competencies, which were developed based on deep industry knowledge enable its clients to surmount challenges, identify business opportunities and exploit them. In the third and fourth paragraphs, KPMG contend that the international standardization of its consulting services (which lies at the heart of its operations) allows it to deliver the same quality of consulting services to clients globally. KPMG's emphasis on the provision of management consulting services to multinational firms contributes immensely to the development of rich and deep industry knowledge necessary to address or solve a wide variety of problems and opportunities being confronted by clients across a variety of industries. The last paragraph makes reference to KPMG's reputation based history and how it has evolved as top international consulting firm over three hundred years.

Deloitte Touche Tohmatsu: This business name emerged by combining the names of the firm's benefactors. This naming approach has been described in theoretical literature as a pure synergistic (nonconcatenated) redeployment (see). The introductory statement in this text, which is entitled "Living the brand" underscores the role of Deloitte Touche Tohmatsu's corporate identity in the firm's business operations and how the pursuit of this brand helps in the development of it's corporate identity (i.e. who and what it is). The first paragraph furthers this argument by highlighting Deloitte Touche Tohmatsu's unique value proposition, which underscores Deloitte Touche Tohmatsu's business challenges and desires, and how Deloitte Touche Tohmatsu's unique contribution and services is effectively differentiated from competitors. Deloitte Touche Tohmatsu's unique value proposition emerges from the consulting services it provides through its large staff strength in many countries throughout the world. The presence of this firm throughout the world implies that it is a strong multinational firm. In the second paragraph, Deloitte Touche Tohmatsu contend that its clients and stakeholders alike experience a combined set of values namely commitment to service, integrity, trust, top quality services, independence and excellence. These virtues constitute Deloitte Touche Tohmatsu's core values and a significant proportion of its corporate identity. Deloitte Touche Tohmatsu's corporate identity is communicated through a formidable staff strength of over 150,000 employees (throughout the world) who interact daily with clients and stakeholders. These interactions lie at the heart of the development of Deloitte Touche Tohmatsu's corporate identity. At the centre of these interactions is the deep knowledge that emerges from the strong formidable network of employees. These knowledge based interactions drive the development of the Deloitte Touche Tohmatsu brand. The third paragraph addresses the notion of ethics and sustainability and how these are expressed through interactions between Deloitte Touche Tohmatsu and its stakeholders.

PricewaterhouseCoopers: The name of this firm appears to be a combination of names (see Jaju et al, 2006). The message expressed in this text implies that PWC is a strong multinational professional services firm, which provides a wide array of management and financial consulting services ranging from assurance, tax and advisory services through a staff strength of over 146,000 employees located at various offices all over the world. This enables PricewaterhouseCoopers to tap from a rich business knowledge derived from a large network of employees who interact to provide solutions to clients' problem. 


\subsubsection{Myth Stage: the Development of a Generic Corporate Identity}

The signifiers that emerged from the connotative stage of Ernst \& Young; KPMG; Deloitte Touche Tohmatsu; PricewaterhouseCoopers (i.e. name combination; multinational institution; standardized top quality auditing, tax, advisory services; large staff strength/network; knowledgeable and well-informed employees; unique problem solving skills; support for client's businesses and the communities) invoke powerful myths. These myths include issues about 'industry leadership', 'strength arising from a combination of names of benefactors', 'international presence', 'consistent international professional service quality', 'deep business knowledge', 'intelligent and knowledgeable staff', exceptional problem solving skills. The evocation of these myths draws the audience closer and positions them as stakeholders with interests in the firms' business activities. The myths presents stakeholders with more information concerning the identity of the four PSFs, especially in relation to its presence at most locations all over the world, strength arising from a combination of names previous benefactors, its ability to provide consistent and standardized top quality professional services, the availability of a large number of employees who are deeply knowledgeable and well-informed to provide unique solutions to business problems. The invocation of these homogeneous corporate characteristics builds a set of associations or myths, around the four PSFs, forming a significant proportion of the key issues that constitute their identity and more importantly their corporate identity. The development of common corporate characteristics triggers the development of a generic corporate identity in the professional services industries.

\section{How a Generic Corporate Identity Develops in Professional Services Firms}

Without any doubt, previous studies (Wilkinson and Balmer, 1996; Morison, 1997; Harris, 2002; He and Balmer, 2005; Balmer and Stotvig, 1996; Olins, 1978; Melewar and Akel, 2005; Melewar and Jenkins, 2002; Melewar and Wooldridge, 2001; Melewar, 2003; Baker and Balmer, 1997; van Riel and Balmer, 1997) together with the empirical analysis presented in paragraphs 3 to 3.1 .3 above contributes significantly to the development and understanding of corporate identity theory. Specifically, existing literature on this subject highlighted and drew attention to the pre-eminence of the generic corporate identity within the British banking industry and in other industries. It provides insight into the possible approaches that could be drawn to manage this phenomenon, gave insight into the causative factors that trigger the development of a generic corporate identity. It highlighted the character, nature, history and identity of the banks in the British banking industry and more importantly, existing work on this subject adds to and strengthens the theoretical literature on corporate identity. Whilst these studies contributed enormously to the understanding of the nature of generic corporate identity in general, they are however limited by their failure to provide a detailed stage by stage insight into the processes through which generic corporate identity emerges.

In order to fill this gap, a four stage generic corporate identity process model is advanced to provide an understanding of the stage by stage processes through which a strong industry-wide corporate identity develops. Insight into this process will provide detailed insight into factors that activate the phenomenon as well as the relationships that subsists within the processes and structures, which trigger the emergence of this problem.

The generic corporate identity process model being proposed under this paragraph is developed by drawing heaving on the DiMaggio and Powell's (1983) theory of institutional isomorphism, which describes a constraining phenomenon, which forces one unit within a defined population to resemble other units that face similar environmental business conditions (Hawley, 1968). This process model, which comprises mainly of a four stage process including (1) evaluation of industry isomorphic conditions; (2) the exertion and application of pressure; (4) conformity and compliance; (4) the development of generic corporate identity; is presented in the paragraphs that follow.

Stage one: industry isomorphic conditions: The industry isomorphic phase comprises of three forms of isomorphic pressures namely mimetic isomorphism, coercive isomorphism and normative isomorphism (DiMaggio and Powell, 1983).

Mimetic isomorphism occurs from a variety of conditions in which firms limit uncertainty by taking a cue from other firms and modeling themselves, their business activities and business behaviour after other firms that are perceived to be very successful (DiMaggio and Powell, 1983; Cyert and James, 1963; Haunschild, 1994; Haverman, 1993). At this stage, executives of a firm that is very familiar with development phases of a successful product or brand belong to a competitor may endeavor to develop a product development plan. On many occasions, the development plans of successful product or service brands are simply copied, replicated or imitated regardless of whether or not these plans are compatible to the firm's corporate identity. It is often a rational response to competition in the marketplace to economise the cost of research and to reduce the uncertainty that firms and businesses face (Cyert and James, 1963) in the marketplace. 
Imitative behaviour occurs when organizations are not convinced of the possibility of achieving set targets or when they are challenged by the difficulties of recognizing the cause effects of adopting specific strategies. Lieberman and Asaba (2006) argue that in such conditions of doubt, uncertainty and ambiguity, organisations are more likely to be receptive to information and implicit in the actions of others. Firms imitate one another through the introduction of products into the marketplace and even in the processes involved in the introduction of such new products. Organisational imitation concurs in management systems, organizational forms, market entry and even in the timing of investment to forestall falling behind competitors, or because the activities of major market actors convey useful and strategic information which can be exploited with ease. Although the modelled organisation may be unaware of emerging imitation, nevertheless, it serves as a useful and convenient source of practices that borrowing firms use. As DiMaggio and Powell (1983) observed, imitative behaviour frequently occurs unintentionally and indirectly through employee transfer or turnover or explicitly through the use of similar business model processes by consulting organisations - the resultant effect of which, homogenisation or generic identity occurs throughout the industry.

Coercive isomorphism emerges out of the conditions of formal demands on business organizations by exogenous forces (Meyer and Rowan, 1977; Oliver, 1991; Honig and Karlsson, 2004). Coercive isomorphism, DiMaggio and Powell (1983) argues, is the consequence of formal and informal unified pressures of forces and persuasion exerted by regulatory institutions on other organizations to conform and comply with a specific set of rules upon which they are dependent and by cultural expectations in the society within which organizations function. The existence of a common system of rules, policies and common legal framework in which organizations comply affects many aspects of organizational behaviours, processes and structure. Coercive isomorphism is the outcome of the making of a common system of rules, policies and common legal framework stipulated (by successive governments and regulatory institutions) to encourage or persuade firms and businesses to imbibe a specific set of rules upon which they are dependent (DiMaggio and Powell, 1983). The occasional specification of interest rates by the Bank of England is a good example in this regard. Normative isomorphism (in a nutshell) is the result of professional procedures and activities generally conceived as a norm and a responsible behaviour within the business environment (Honig and Karlsson, 2004). It is a collective attempt by members of an occupation to define the methods and conditions of work and to control the production of producers (Larson, 1977). It is a means of establishing a cognitive base, legitimizing their profession and developing an occupational autonomy (DiMaggio and Powell, 1983). Normative isomorphism often emerges from the adoption of professional procedures stipulated by professional institutions like the ACCA, CIMA, ICSA, CIM and CIPD.

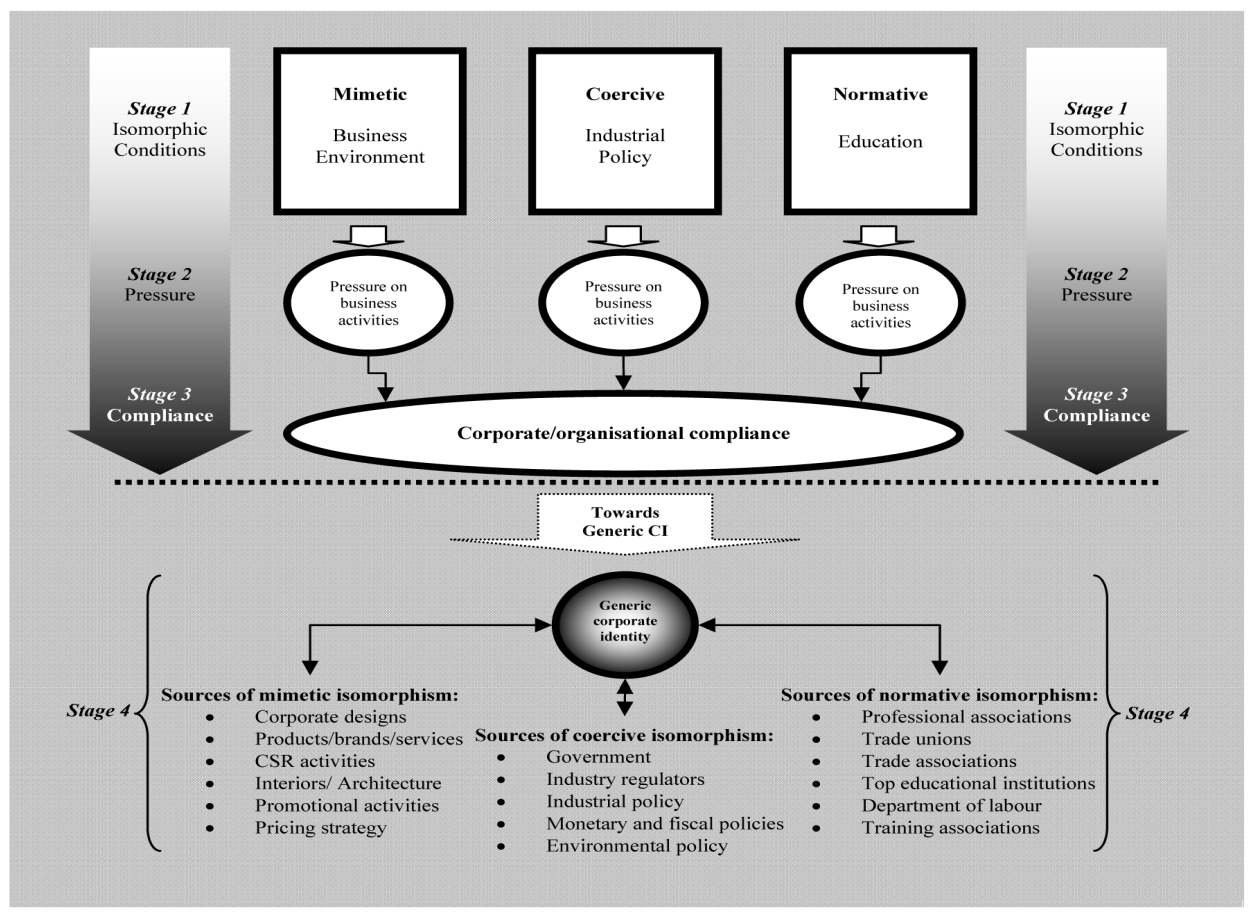

Figure 1. The development of generic corporate identity

Source: developed by author 
Stage two: the exertion of institutional pressures: The imitation of products, making of a common and unified system of policies, rules and regulations and the development of formal professional procedures are often times pursued with the backing of institutional powers and authority to sanction or prosecute business. The power and authority conferred on businesses also allows regulators or managers to monitor the implementation of industry regulations, professional practices and so on. Importantly, the power to sanction or prosecute defaulting firms and monitor their business activities inevitably puts a severe amount of pressure on businesses to implement industry policies.

Stages three and four: compliance and development a generic corporate identity: The existence of a common system of rules, policies and common legal framework in which organizations comply affects many aspects of organizational behaviours, processes and structure. Hence, in the course of compliance, industry operators begin to exhibit similar traits in behaviour and a dominant industry-wide (generic) identity emerges. Similarly in the business environment, when unified regulatory policies are initiated by regulators, most organizations in the market will adopt overall, unified compliance programmes emphasizing the pursuit of common policies, common procedures, and common work rules. These programmes often feature common methodologies, structures and templates for meeting current and anticipated compliance requirements (Gable 2005) resulting in the development of common, similar, uniform, regular, standardised, identical product/services, pricing strategy, distribution and organizational intentions. Importantly, these common organizational characteristics, or what $\mathrm{He}$ and Balmer (2005) described as a unique type of identity incorporating characteristics attributable mainly to a specific industry - generic identity, will emerge. The banking industry gives a good example of how compliance with regulatory policies has led to the development of generic identities.

\section{Conclusion}

This study provides insight into the dominant arguments in generic corporate identity literature and offers an empirically grounded evidence of the presence of generic corporate identity in professional services industry. In the attempt to accomplish this objective, three important findings emerged. First, a tripartite study of the theoretical construction of the generic corporate identity incorporating active, passive and parenthetically constructed discourses was put forward. While, actively constructed discourse (Wilkinson and Balmer, 1996; Morison, 1997; Harris, 2002; He and Balmer, 2005) was drawn to capture key arguments appearing in works devoted primarily to generic corporate identity theory, passively constructed discourse (Balmer and Stotvig, 1997; Olins, 1978) highlighted works, which (in part) drew considerable attention to the concept of generic corporate identity. Parenthetically constructed discourse (Baker and Balmer, 1997; Melewar and Akel, 2005; Melewar and Jenkins, 2002; Melewar and Wooldridge, 2001; Melewar, 2003; van Riel and Balmer, 1997) underscored studies that briefly highlight or drew attention to generic corporate identity in-passing or incidentally. This finding contributes to the theory of corporate identity and corporate marketing in general because until date there has been no theoretical literature highlighting the academic progress on generic corporate identity.

Second, the semiotic analysis of annual report of accounts of the big four professional services firms strengthens the argument of the prevalence of a generic business behaviour (see Empson, 2001; Løwendahl, 2005) not just within the British banking or financial services industry but also within the confines of the professional services sector.

In view of the absence of a theoretical framework that explicates the development of generic corporate identity in literature, a generic corporate identity development process model was conceptualised and advanced. This model, grounded on DiMaggio and Powell's (1983) institutional isomorphism theory, drew attention to the role of mimetic, coercive and normative isomorphism pressures and offers some insight into how business compliance stimulate the development of a generic corporate identity. This finding contributes to corporate identity theory because a model, which gives an insight into structures that triggers a generic corporate identity, is yet to emerge in corporate marketing literature. This represents the third contribution in this study.

The review of literature indicates that existing studies on corporate identity has focused mainly of the factors that trigger the development of a generic corporate identity without a detailed explanation how this concept emerged. This paper is important and valuable because it makes a departure from extant theory and adds an original contribution to existing literature by providing a theoretical analysis, which gives an insight into the stage by stage processes that trigger the development of a generic corporate identity.

The key implication of this study for practitioners is that it draws the attention of managers not just to the important issues that trigger the development of a generic corporate identity but more importantly, it allows managers to pin point develop strategies that can prevent or circumvent the development of generic corporate 
identity (each step of the way). By so doing, it becomes possible for firms to develop distinct corporate identities, which position them competitively in the business environment.

One important limitation that provides opportunities for future research has to do with the nature of this study itself. This is an empirical study that focuses mainly on PSFs. The study could not examine the nature of generic corporate identity in other service industries. Given this limitation, it has become important for researchers to pursue further studies to examine this issue in tourism, information technology and other industries where there is a presence of generic corporate identity. Such a study will strengthen and give deeper and robust insight into how the notion of generic corporate identity develops. Also the study is limited to the development of generic corporate identity. A future study of how a generic corporate identity could be broken would be useful not just to academics or the development of corporate identity literature but to practitioners as well.

\section{References}

Abratt, R. (1989). A new approach to the corporate image management process. Journal of Marketing Management, 5(1), 63-76. http://dx.doi.org/10.1080/0267257X.1989.9964088

Baker, M. J., \& Balmer, J. M. T. (1997). Visual identity: trappings or substance? European Journal of Marketing, 31(5), 366-382. http://dx.doi.org/10.1108/03090569710167592

Balmer, J. M. T., \& Greyser, S. A. (2003). Revealing the corporation: perspectives on identity, image, reputation, corporate branding and corporate-level marketing. Routledge, London.

Balmer, J. M. T., \& Stotvig, S. (1997). Corporate Identity and Private Banking: A Review and Case Study. International Journal of Bank Marketing, 15(5), 169-184. http://dx.doi.org/10.1108/02652329710175370

Balmer, J. M. T., \& Wilkinson, A. (1991). Building societies: change strategy and corporate identity. Journal of General Management, 17(2), 20-33.

Barthes, R. (1967). Elements of semiology. Hill and Lang, New York.

Barthes, R. (1988). Camera lucida. Fontana, London.

Barthes, R. (1972). Mythologies. Hill and Lang, New York.

Capowski, G. S. (1993). Designing a corporate identity. Management Review, 82(6), 37-40.

Chandler, D. (2007). Semiotics: the basics. Routledge, London.

Cyert, R. M., \& James, G. (1963). A behavioral theory of the firm. Englewood Cliffs, New Jersey.

de Saussure, F. (1916). Course in general linguistics. (trans. Roy Harris) London.

Deloitte Touche Tohmatsu. (2007). Milestones on the journey. Deloitte Touche Tohmatsu World-wide member firms annual review.

DiMaggio, P. J., \& Powell, W. W. (1983). The iron cage revisited: institutional isomorphism and collective rationality in organisational fields. American Sociological Review, 48(2), 147-160. http://dx.doi.org/10.2307/2095101

Downey, S. M. (1986). The relationship between corporate culture and corporate Identity. Public Relations Quarterly, Winter, 7-12.

Eco, U. (1976). A Theory of Semiotics. Indiana University Press, Bloomington.

Empson, L. (2001). Fear of exploitation and fear of contamination: impediments to knowledge transfer in mergers between professional service firms. Human Relations, 54(7), 839-862. http://dx.doi.org/10.1177/0018726701547003

Ernst \& Young. (2007). Global review 2007.

Forbes. (2007). America's largest private companies. Retrieved from http://www.forbes.com/lists/2007/21/biz_privates07_Americas-Largest-Private-Companies_Rank.html (June 3, 2008)

Gable, J. (2005). Navigating the compliance landscape. The Information Management Journal, July/August.

Hall, S. (1999). Representation: cultural representations and signifying practices. Sage/Open University, London.

Harris, G. (2002). Brand strategy in the retail banking sector: adapting to the financial services revolution. Journal of Brand Management, 9(6), 430-436. http://dx.doi.org/10.1057/palgrave.bm.2540090 
Haunschild, P. (1994). How much is that company worth? Interorganizational relationships, uncertainty, and acquisition premiums. Administrative Science Quarterly, 44, 391-411. http://dx.doi.org/10.2307/2393296

Haverman, H. A. (1993). Follow the leader: mimetic isomorphism and entry into new Markets. Administrative Science Quarterly, 38, 593. http://dx.doi.org/10.2307/2393338

Hawley, A. (1968). Human ecology. In D. L. Sills (Ed.), The international encyclopedia of the social sciences (pp. 328-337). New York: Crowell, Collier Macmillan.

He, H., \& Balmer, J. M. T. (2005). The saliency and significance of generic identity: an exploratory study of UK building societies. International Journal of Bank Marketing, 23(4), 334-348. http://dx.doi.org/10.1108/02652320510603951

Honig, B., \& Karlsson, T. (2004). Institutional forces and the written business plan. Journal of Management, 30(1), 29-48. http://dx.doi.org/10.1016/j.jm.2002.11.002

Howcroft, J., \& Lavis, J. (1986). Image in retail banking. International Journal of Bank Marketing, 4(4), 3-13. http://dx.doi.org/10.1108/eb010786

Jaju, A., Joiner, C., \& Reddy, S. K. (2006). Consumer evaluations of corporate brand redeployments. Journal of the Academy of Marketing Science, 34(2), 206-215. http://dx.doi.org/10.1177/0092070305284989

KPMG. (2007). Borderless markets boundless opportunities. KPMG international annual review.

Larson, M. S. (1977). The rise of professionalism. University of California Press, Berkeley, CA.

Lieberman, M. B., \& Asaba, S. (2006). Why do firms imitate each other? Academy of Management Review, 31(2), 366-385. http://dx.doi.org/10.5465/AMR.2006.20208686

Løwendahl, B. R. (2005). Strategic management of professional service firms. Copenhagen Business School Press.

Leiss, W., Kline, S., \& Jhally, S. (1986). Social Communication in Advertising: Persons, Products and Images of Well-being. Methuen, Toronto.

Melewar, T. C. (2003). Determinants of the corporate identity construct: a review of literature. Journal Marketing Communications, 9(3), 195-220. http://dx.doi.org/10.1080/1352726032000119161

Melewar, T. C., \& Sibel Akel. (2005). Corporate identity in the higher education sector: A case study. Corporate Communications: An International Journal, 10(1), 41-27. http://dx.doi.org/10.1108/13563280510578196

Melewar, T. C., \& Jenkins, E. (2002). Defining the corporate identity construct. Corporate Reputation Review, 5(1), 76 - 90. http://dx.doi.org/10.1057/palgrave.crr.1540166

Melewar, T. C., \& Wooldridge, A. (2001). The dynamics of corporate identity: a review of a process model. Journal of Communication Management, 5, 327- 340. http://dx.doi.org/10.1108/13632540110806866

Merris, G. (2001). Children's toy advertisements. Ph.D. Thesis, University of Wales, Aberystwyth.

Meyer, J., \& Rowan, B. (1977). Institutionalized organizations: Formal structure as myth and ceremony. American Journal of Sociology, 83, 340-363. http://dx.doi.org/10.1086/226550

Mick, D. G. (1986). Consumer research and semiotics: exploring the morphology of signs, symbols, and significance. Journal of Consumer Research, 13(2), 196-213. http://dx.doi.org/10.1086/209060

Morison, Ian. (1997). Breaking the monolithic mould. International Journal of Bank Marketing, 15(5), 153-162. http://dx.doi.org/10.1108/02652329710175253

Olins, W. (1978). The corporate personality: an inquiry into the nature of corporate identity. Design Council, London.

Oliver, C. (1991). Strategic responses to institutional responses. Academy of Management Review, 16(1), 145-179.

Otubanjo, B. O., \& Melewar, T. C. (2007). Understanding the meaning of corporate identity: a conceptual and semiological approach. Corporate Communications: An International Journal, 12(4), 414-432. http://dx.doi.org/10.1108/13563280710832542

Otubanjo, B. O. (2008). Industry construction of the meaning of corporate identity in the Nigerian banking services sector: an interpretive analysis of corporate advertisements, 1970-2005. Unpublished $\mathrm{PhD}$ thesis, Brunel University, London. 
Phillips, N., \& Brown, J. L. (1993). Analysing communication in and around organisations: a critical hermeneutic approach. Academy of Management Journal, 36(6), 1547-1576. http://dx.doi.org/10.2307/256821

PricewaterhouseCoopers. (2007). 07 Global Annual review.

Topalian, A. (1984). Corporate identity: beyond the visual overstatements. International Journal of Advertising, $3(1), 55-62$.

van Riel, C. B. M., \& Balmer, J. M. T. (1997). Corporate identity: the concept, its measurement and management. European Journal of Marketing, 31(5), 340-355.

Wilkinson, A., \& Balmer, J. M. T. (1996). Corporate and generic identities: lessons from the Co-operative Bank. International Journal of Bank Marketing, 14(4), 22-35. 